\title{
Emulsifier in Broiler Diets Containing Different Fat Sources
}

-Author(s)
Guerreiro Neto AC1
Pezzato AC ${ }^{2}$
Sartori JR²
Mori C
Cruz VC
Fascina VB
Pinheiro DF
Madeira LA
Gonçalvez JC ${ }^{3}$
1 M.Sc. in Animal Science, Post-Graduation
Program in Animal Science - FMVZ/NESP.
Botucatu, São Paulo, Brazil.
2 Assist. Prof., Ph.D., Department of Animal
Breeding and Nutrition - FMVZ/UNESP.
Botucatu, São Paulo, Brazil.
3 Ph.D. in Animal Science, Post-Graduation
Program in Animal Science - FMVZ/UNESP.
Botucatu, São Paulo, Brazil.
4 Assist. Prof., Ph.D., School of Animal
Science, UNESP. Dracena, São Paulo, Brazil.
5 Ph.D. Student of the Post-Graduation.
Program in Animal Science - FMVZ/UNESP.
Botucatu, São Paulo, Brazil.

\section{-Mail Adress}

José Roberto Sartori

Departamento de Melhoramento e Nutrição Animal. FMVZ/UNESP

18.618-000. Botucatu, SP, Brasil

E-mail: jrsartori@fmvz.unesp.br

\section{-Keywords}

Digestibility, pancreatic lipase, performance, poultry offal fat, serum lipids, soybean oil.

\begin{abstract}
This present study aimed at evaluating the effect of the addition of an emulsifier to diets containing soybean oil, poultry fat or their blend, on the performance, carcass traits, serum lipid levels, pancreatic lipase concentration and nutrient digestibility of broilers. A randomized block design was applied using a $3 \times 2$ factorial arrangement, with three fat sources (soybean oil, poultry fat, and a blend of $50 \%$ soybean oil and $50 \%$ poultry fat) and the addition or not of an emulsifier. In experiment I, broiler performance, carcass traits, serum cholesterol, $\mathrm{HDL}$, and triglyceride levels, and pancreatic lipase activity in 42-day-old broilers were evaluated. In experiment II, dry matter (DM), ether extract (EE), crude protein (CP) and crude fiber (CF) coefficients of digestibility were analyzed. Broilers fed the diet containing soybean oil and emulsifier presented higher body weight, weight gain and better feed conversion ratio. When birds were fed poultry fat and the fat blend (soybean oil and poultry fat) and the emulsifier was added to the diets, pancreatic lipase concentration increased. It was concluded that the use of soybean oil, poultry fat and their blend does no in the diet does not influence the performance, carcass traits, or serum cholesterol, $\mathrm{HDL}$ and triglyceride levels of 42-day-old broilers. The addition of emulsifiers to diets containing poultry fat improves ether extract digestibility and increases the production and secretion of pancreatic lipase.
\end{abstract}

\section{INTRODUCTION}

The continuous genetic improvement of broiler genetic lines result in continuous changes in their nutritional requirements, demanding improvements in feed formulation and manufacturing in order to supply these requirements. The addition of fat sources increases dietary energy levels, and consequently, feed efficiency. However, it must be considered that fat absorption increases with bird age, as young broilers have a physiological limitation to absorb that nutrient (Jeason \& Kellog, 1992; Nir et al., 1993; Lima et al., 2003).

Those physiological limitations of the digestive system of poultry may be overcome using endogenous and/or exogenous strategies to maximize feed digestion and absorption. The addition of synthetic emulsifier to broiler diets is a recent practice as compared to other dietary supplements. The mode of action of emulsifiers is to increase the active surface of fats, allowing the action of lipase, which hydrolyze triglyceride molecules into fatty acids and monoglycerides and favor the formation of micelles consisting of lipolysis products. This is an essential step for lipid absorption, as its creates a diffusion gradient that increases absorption.

Among emulsifiers, casein has become an important feed additive. Its main sources are skimmed powdered milk and soluble caseinates, 
which are heterogeneous protein aggregates, which are the most important components involved in the emulsification of beta-casein, presenting proline residues (Araújo, 1999).

There are many studies on the influence of age on the use of vegetable oils and animal fats. Young poultry present lower fat digestion capacity as compared to older birds and are not physiological capable of responding to the energy levels included in pre-starter and starter diets (Carew Jr. et al., 1972; Krogdhal, 1985; Sell et al., 1986; Jeason \& Kellog, 1992; Nir et al., 1993; Lima et al., 2003).

The objective of the present study was to evaluate the effect of the addition of a commercial emulsifier composed by casein to broiler diets containing soybean oil, poultry fat and their combination on broiler performance, carcass traits, blood cholesterol, triglycerides and HDL-cholesterol levels, pancreatic lipase concentration, and nutrient digestibility.

\section{MATERIALS AND METHODS}

Two experiments were carried out at the Poultry Nutrition Lab of the School of Veterinary Medicine and Animal Science, Univ. Estadual Paulista (UNESP), Botucatu, Brazil.

In experiment I, 720 one-day-old male Cobb broilers were used. Chicks were vaccinated in the hatchery against infectious bursal disease, Marek's disease, and fowl pox. Birds were housed in 24 pens measuring $2.5 \mathrm{~m}^{2}$ in a conventional broiler house equipped with trough feeders and bell drinkers. Brooding was provided by infrared lamps. House temperature and ventilation were manually controlled to maintain broiler comfort temperature, according to the genetic line manual. A $24 \mathrm{~h}$ of light lighting program was adopted.

A randomized block design was applied using a $3 \times 2$ factorial arrangement, with three fat sources (soybean oil (SO), poultry fat (PF), and a blend of $50 \%$ soybean oil and $50 \%$ poultry fat (SOPF) and the addition or not of an emulsifier, totaling six treatments, with four replicates of 30 birds each.

Feeds were based on corn and soybean meal, and formulated according to the nutritional recommendations of Rostagno et al. (2005). A 3-phase feeding program was adopted: starter (1 - 21 days), grower (22 - 35 days) and finisher (36 - 42 days) (Table 1). Feed and water were provided ad libitum during the entire experimental period. The

Table 1 - Ingredient and calculated composition of the experimental diets.

\begin{tabular}{|c|c|c|c|c|c|c|c|c|c|}
\hline \multirow{2}{*}{ Ingredients } & \multicolumn{3}{|c|}{ Starter } & \multicolumn{3}{|c|}{ Grower } & \multicolumn{3}{|c|}{ Finisher } \\
\hline & So & $\mathrm{PF}$ & SOPF & So & $\mathrm{PF}$ & SOPF & So & $\mathrm{PF}$ & SOPF \\
\hline Ground corn & 54.56 & 54.76 & 54.32 & 59.49 & 60.93 & 60.16 & 62.82 & 64.07 & 63.40 \\
\hline Soybean oil & 3.50 & - & 1.75 & 4.00 & - & 2.00 & 4.50 & - & 2.25 \\
\hline Poultry fat & - & 3.50 & 1.75 & - & 4.00 & 2.00 & - & 4.50 & 2.25 \\
\hline Soybean meal & 37.90 & 37.80 & 38.20 & 32.70 & 31.10 & 32.00 & 29.30 & 28.01 & 28.70 \\
\hline Inert material ${ }^{1}$ & 0.05 & 0.05 & 0.05 & 0.05 & 0.05 & 0.05 & 0.05 & 0.05 & 0.05 \\
\hline Salt & 0.50 & 0.40 & 0.40 & 0.40 & 0.40 & 0.40 & 0.40 & 0.40 & 0.40 \\
\hline Limestone & 1.10 & 1.10 & 1.15 & 1.05 & 1.00 & 1.05 & 1.05 & 1.00 & 1.00 \\
\hline Dicalcium phosp. & 1.80 & 1.80 & 1.80 & 1.65 & 1.80 & 1.65 & 1.55 & 1.60 & 1.60 \\
\hline DL-methionine & 0.17 & 0.17 & 0.17 & 0.15 & 0.16 & 0.16 & 0.12 & 0.12 & 0.12 \\
\hline L-lysine $\mathrm{HCl}$ & 0.07 & 0.07 & 0.06 & 0.15 & 0.16 & 0.13 & 0.01 & 0.05 & 0.03 \\
\hline Vit./Min. Suppl. ${ }^{2}$ & 0.40 & 0.40 & 0.40 & 0.40 & 0.40 & 0.40 & 0.20 & 0.20 & 0.20 \\
\hline Total & 100.00 & 100.00 & 100.00 & 100.00 & 100.00 & 100.00 & 100.00 & 100.00 & 100.00 \\
\hline \multicolumn{10}{|l|}{ Calculated values } \\
\hline Crude protein, \% & 21.79 & 21.76 & 21.91 & 19.80 & 19.18 & 19.53 & 18.50 & 18.00 & 18.27 \\
\hline $\mathrm{AME}, \mathrm{kcal} / \mathrm{kg}$ & 3.055 & 3.049 & 3.051 & 3.150 & 3.148 & 3.148 & 3.223 & 3.220 & 3.220 \\
\hline Methionine, \% & 0.49 & 0.49 & 0.50 & 0.46 & 0.45 & 0.40 & 0.40 & 0.40 & 0.41 \\
\hline Met.+Cys., \% & 0.86 & 0.86 & 0.87 & 0.79 & 0.78 & 0.79 & 0.73 & 0.72 & 0.72 \\
\hline Lysine, \% & 1.28 & 1.27 & 1.28 & 1.16 & 1.16 & 1.17 & 0.99 & 1.00 & 0.99 \\
\hline Calcium, \% & 0.98 & 0.98 & 1.00 & 0.91 & 0.92 & 0.91 & 0.88 & 0.87 & 0.87 \\
\hline Total phosp., \% & 0.68 & 0.68 & 0.68 & 0.64 & 0.66 & 0.64 & 0.61 & 0.62 & 0.62 \\
\hline Ether extract, \% & 5.82 & 5.79 & 5.79 & 6.45 & 6.46 & 6.46 & 7.05 & 7.05 & 7.02 \\
\hline
\end{tabular}


Guerreiro Neto AC, Pezzato AC, Sartori JR, Mori C, Cruz VC, Fascina VB
Emulsifier in Broiler Diets Containing Different Fat Sources emulsifier used in the present study consisted of milkderived casein.

Performance parameters were evaluated for the cumulative periods of 1 to 7,1 to 14 and 1 to 42 days of age. Body weight was obtained by weighing together of all birds of each experimental unit at housing and at 7, 14 and 42 days of age; weight gain was calculated as the difference between body weight at the end of period and weight at housing. Feed intake was calculated as to difference between the total amount of feed supplied and feed residues at the end of each period. Feed conversion ratio was calculated as the ratio between total feed supplied and weight gain in each period and corrected for the weight of birds that died during that period. Mortality was daily recorded and expressed as a percentage of the ratio of the number of dead birds during each period to the number of birds housed. Production factor was calculated as by dividing daily weight gain $(\mathrm{kg})$ times livability (\%) by feed conversion ratio and multiplied by 100 .

At the end of the experimental period, five birds per experimental unit (20 birds per treatment) were randomly chosen and submitted to $8 \mathrm{~h}$ fasting and weighed. These birds were then stunned, bled, defeathered, eviscerated, and their abdominal fat pad was removed. Carcasses with no feet, head and neck were weighed to determine carcass yield relative to live slaughter weight, and subsequently cut up and de-boned to obtain the following parts yield relative to carcass weight: breast, breast meat, breast bones, breast skin, leg (thighs+drumsticks), back, and wings. Feet, head+neck, abdominal fat pad, and gizzard yields were determined relative to live weight before slaughter (Sartori et al., 1997).

At 42 days of age, one bird per experimental unit was randomly selected for the collection of $5 \mathrm{~mL}$ of blood by brachial vein puncture, and the obtained serum was analyzed for total cholesterol total, triglycerides and high-density lipoprotein (HDL) by colorimetric enzymatic method using a commercial kit $\left(\mathrm{Celm}^{\circledR}\right)$, with reading at $505 \mathrm{~nm}$ in spectrophometer, according to the method of Lumeij (1997). The results were expressed in $\mathrm{mg} / \mathrm{dL}$. These birds were then sacrificed, and had their pancreas removed for the analysis of pancreatic lipase (Sarda \& Desnuele, 1958) using a commercial kit (In vitro Diagnóstica - Renylab ${ }^{\circledR}$ ) with reading at $412 \mathrm{~nm}$ absorbance in spectrophotometer. The results were expressed in IU/kg pancreas.

In experiment II, 72 one-day-old male Cobb broilers were used. Chicks were vaccinated in the hatchery against infectious bursal disease, Marek's disease, and fowl pox. Birds were housed in 24 galvanized iron cages $(0.50 \mathrm{~m}$ high, $0.50 \mathrm{~m}$ wide, $0.60 \mathrm{~m}$ deep).

A randomized block design was applied using a $3 \times 2$ factorial arrangement, with three fat sources (soybean oil (SO), poultry fat (PF), and a blend of $50 \%$ soybean oil and $50 \%$ poultry fat (SOPF) and the addition or not of an emulsifier, totaling six treatments with four replicates of three birds each. The experimental diets used in this experiment had the same ingredient and calculated compositions as those used in experiment I.

In order to determine dietary nutrient digestibility, excreta samples were collected every 12 hours for three consecutive days after day 21. Excreta were placed in plastic bags and stored at $-20{ }^{\circ} \mathrm{C}$. At the end of the collection period, excreta samples were thawed, homogenized, and pre-dried in a forcedventilation oven at $55{ }^{\circ} \mathrm{C}$ for 72 hours, after which they were ground for subsequent analyses. Dry matter $(D M)$, ether extract (EE), crude protein $(C P)$ and crude fiber (CF) contents were determined according to the methodology recommended by the AOAC (1990) and the coefficients of digestibility were calculated according to the method proposed by Matterson et al. (1965).

At the end of the excreta collection period ( 24 days of age), one bird/cage was sacrificed to determine the activity of pancreatic lipase. The collection and analysis procedures were the same as those used in experiment I.

Data were submitted to analysis of variance using the General Linear Model procedure of SAS software package (1996). Means were compared by the test of Tukey at $5 \%$ probability.

\section{RESULTS AND DISCUSSION}

There was no effect of fat source or of the addition of the emulsifier on the performance of 7-day-old broilers (Table 2). These results are consistent with the findings of Vieira et al. (2002), who added $4 \%$ soybean soapstock to broiler diets and did not observe any differences in performance. Gaiotto (2004) also did not find any differences in the performance of 7-day-old broilers fed soybean oil or poultry fat at 3.98 and $4.19 \%$ inclusion levels, respectively, which were similar to the $3.5 \%$ levels used in the present study. The use of an emulsifier did not improve the performance of 7-day-old broilers possibly due to their low lipase activity during this period (Jeason \& Kellog, 1992; Nir et al., 1993).

At 14 days of age there was significant effect $(p<0.05)$ of the interaction between fat sources and 
Table 2 - Mean initial weight (IW), body weight (BW), weight gain (WG), feed intake (FI), feed conversion ratio (FCR), mortality (MO) and production factor (PF) of broilers fed diets with different fat sources and with or with no addition of an emulsifier.

\begin{tabular}{|c|c|c|c|c|c|c|c|c|c|}
\hline \multirow{2}{*}{ Parameter } & \multicolumn{2}{|c|}{ Emulsifier (E) } & \multicolumn{3}{|c|}{ Fat source (F) } & \multicolumn{3}{|c|}{ Probability } & \multirow{2}{*}{$\begin{array}{c}\text { CV } \\
(\%)^{3}\end{array}$} \\
\hline & Without & With & $\mathrm{SO}^{1}$ & $\mathrm{PF}^{1}$ & SOPF1 & $E$ & $\mathbf{F}$ & ExF & \\
\hline IW, g & 46 & 46 & 46 & 45 & 46 & ns & ns & ns & 0.60 \\
\hline \multicolumn{10}{|c|}{7 days of age } \\
\hline BW, g & 179 & 181 & 179 & 180 & 180 & ns & $\mathrm{ns}$ & $\mathrm{ns}$ & 1.83 \\
\hline WG, g & 133 & 135 & 133 & 135 & 135 & ns & ns & ns & 2.50 \\
\hline $\mathrm{Fl}, \mathrm{g}$ & 148 & 148 & 148 & 146 & 149 & ns & ns & ns & 3.68 \\
\hline FCR & 1.11 & 1.10 & 1.12 & 1.09 & 1.10 & ns & ns & ns & 4.21 \\
\hline $\mathrm{MO}^{2}, \%$ & 0.27 & 0.27 & 0.83 & 0.00 & 0.00 & ns & ns & ns & 42.99 \\
\hline \multicolumn{10}{|c|}{14 days of age } \\
\hline BW, g & 491 & 500 & 489 & 499 & 500 & $p<0.05$ & $p<0.05$ & $p<0.05$ & 1.40 \\
\hline WG, g & 445 & 454 & 442 & 453 & 454 & $p<0.05$ & $p<0.05$ & $p<0.05$ & 1.55 \\
\hline $\mathrm{Fl}, \mathrm{g}$ & 547 & 544 & 544 & 546 & 547 & ns & ns & ns & 1.55 \\
\hline FCR & 1.23 & 1.20 & 1.23 & 1.21 & 1.20 & $p<0.05$ & $p<0.05$ & $p<0.05$ & 1.50 \\
\hline $\mathrm{MO}^{2}, \%$ & 0.55 & 1.39 & 1.66 & 0.83 & 0.42 & ns & ns & $\mathrm{ns}$ & 57.95 \\
\hline \multicolumn{10}{|c|}{42 days of age } \\
\hline BW, g & 2673 & 2711 & 2699 & 2687 & 2691 & ns & $\mathrm{ns}$ & ns & 2.58 \\
\hline$W G, g$ & 2673 & 2711 & 2653 & 2641 & 2645 & ns & ns & ns & 2.63 \\
\hline $\mathrm{Fl}, \mathrm{g}$ & 4281 & 4266 & 4274 & 4304 & 4243 & ns & ns & ns & 2.22 \\
\hline FCR & 1.65 & 1.64 & 1.64 & 1.65 & 1.64 & ns & ns & ns & 1.22 \\
\hline $\mathrm{MO}^{2}, \%$ & 6.94 & 10.28 & 8.33 & 7.50 & 10.00 & ns & ns & ns & 46.55 \\
\hline $\mathrm{PF}$ & 353 & 347 & 353 & 532 & 346 & ns & ns & ns & 7.33 \\
\hline
\end{tabular}

ns: not significant ( $p \geq 0.05)$. 1 - SO: soybean oil; PF: poultry fat; SOPF: $50 \%$ soybean oil and 50\% poultry fat. 2 - Mortality data were submitted to squareroot transformation $(X+0.5) .3$ - CV: coefficient of variation.

emulsifier addition on body weight, weight gain and feed conversion ratio (Table 3). As to the effect of emulsifier addition, birds fed diets with no emulsifier presented better body weight, weight gain and feed conversion ratio when poultry fat and the fat blend were present in the diet. This result indicates that there was a synergistic effect between fat sources.

Table 3 - Details of the effects of the interactions between fat source and emulsifier on body weight, weight gain and feed conversion ratio of 14-day-old broilers.

\begin{tabular}{lccccc}
\hline \multirow{2}{*}{ Parameter } & \multirow{2}{*}{ Emulsifier } & \multicolumn{3}{c}{ Fat source } & \multirow{2}{*}{ Mean } \\
\cline { 2 - 5 } & SO' & PF1 $^{1}$ & SOPF1 & \\
\hline \multirow{3}{*}{ Body weight, g } & Without & $474 \mathrm{Bb}$ & $499 \mathrm{a}$ & $501 \mathrm{a}$ & 491 \\
& With & $502 \mathrm{~A}$ & 499 & 499 & 500 \\
& Mean & 488 & 499 & 500 & \\
Weight gain, g & Without & $428 \mathrm{Bb}$ & $453 \mathrm{a}$ & $455 \mathrm{a}$ & 445 \\
& With & $456 \mathrm{~A}$ & 453 & 453 & 454 \\
& Mean & 442 & 453 & 454 & \\
Feed conversion ratio, g & Without & $1.28 \mathrm{Aa}$ & $1.21 \mathrm{~b}$ & $1.20 \mathrm{~b}$ & 1.23 \\
& With & $1.19 \mathrm{~B}$ & 1.20 & 1.21 & 1.20 \\
\cline { 2 - 5 } & Mean & 1.23 & 1.21 & 1.20 & \\
\hline
\end{tabular}

1 - SO: soybean oil; PF: poultry fat; SOPF: $50 \%$ soybean oil and $50 \%$ poultry fat. $a, b$ - Means followed by different small letters in the same row are significantly different by the test of Tukey $(p<0.05)$. A,B - Means followed by different capital letters in the same row are significantly different by the F test $(p<0.05)$.

As to the effect of fat source, birds fed diets containing soybean oil and supplemented with emulsifier presented better $(p<0.05)$ body weight, weight gain and feed conversion ratio results. The inclusion of the emulsifier did not influence these parameters when poultry fat or the fat blend were used (Table 3). The better body weight and feed conversion ratio of the birds fed the diets with soybean oil and emulsifier may be related to the fatty-acid composition of this fat source and its effects on fat digestion ad absorption. According to Ketels \& DeGroote (1989), the utilization of dietary fat by broilers increases when the ratio between insaturated and saturated fatty acids increased from 0.0 to 2.5 .

At 42 days of age, fat sources and the addition of the emulsifier had no influence on broiler performance (Table 2), which agrees with the results of Ferreira et al. (2005), who did not observe performance differences among broilers fed different ratios of soybean oil and tallow, as well as with Sanz et al. (2000), using sunflower oil and a blend of tallow and lard, and with Manilla et al. (1999) and Andreotti et al. (2004), who did not find any differences among soybean oil levels in the diet.

The results of the present study, however, disagree with the findings of Zollistsch et al. (1997), who found better feed conversion ratio and higher weight gain in 43-day-old broilers fed a diet with soybean oil as compared to a blend of vegetable oil and animal 
fat. Gaiotto et al. (2000) verified better performance of 42-day-old broilers fed a blend of equal parts of soybean oil and tallow.

There was no influence of fat sources or of emulsifier addition on carcass traits (Table 4). These results are consistent with those of Andreotti et al. (2004), Ferreira et al. (2005) and Lara et al. (2006), who also did not observe any differences in carcass and parts yields or in abdominal fat percentage in broilers fed different fat sources.

Total cholesterol, HDL or triglyceride levels were not affected by dietary fat sources or emulsifier addition (Table 5), as observed by Silva et al. (2001) and Fascina et al. (2009), who did not find any HDL differences between broilers fed vegetable oils or animal fat. Ozdogan \& Aksit (2003) also did not observe any differences in triglyceride levels in broilers fed vegetable oil or tallow, whereas Fascina et al. (2009) observed lower triglyceride levels in broilers fed soybean oil as compared to those fed tallow.

The total cholesterol results obtained in the present study are different from those obtained by Crespo \& Esteve-Garcia (2003) and Fascina et al. (2009), who verified higher total cholesterol in broilers fed diets containing animal fat relative to those fed vegetable oils.

Pancreatic lipase levels were influenced by fat sources and emulsifier addition, which effects interacted $(p<0.05)$ when broilers were 24 and 42 days of age (Table 6). At these two evaluated ages, independently of the addition of emulsifier, fat sources did not significantly affect pancreatic lipase secretion. However, within the factor fat sources, 24-day-old broilers fed poultry offal fat presented higher lipase concentration when the diet did not contain emulsifier, and the lowest lipase levels were obtained when broilers were fed the diet containing the fat blend and the emulsifier. In 42-day-old broilers, lípase concentration was higher when diets were supplemented with emulsifier.

Table 5 - Serum levels of total cholesterol, HDL and triglycerides of 42-day-old broilers as a function of fat source and emulsifier inclusion.

\begin{tabular}{|c|c|c|c|}
\hline Parameter & $\begin{array}{c}\text { Total cholesterol } \\
\mathrm{mg} / \mathrm{dL}\end{array}$ & $\begin{array}{l}\mathrm{HDL} \\
\mathrm{mg} / \mathrm{dL}\end{array}$ & $\begin{array}{c}\text { Triglycerides } \\
\mathrm{mg} / \mathrm{dL}\end{array}$ \\
\hline Fat source (F) & ns & ns & ns \\
\hline $\mathrm{SO}^{1}$ & 185.18 & 79.08 & 30.07 \\
\hline $\mathrm{PF}^{1}$ & 179.34 & 80.93 & 29.13 \\
\hline SOPF 1 & 151.02 & 50.85 & 25.90 \\
\hline Emulsifier (E) & ns & ns & ns \\
\hline Without & 169.48 & 73.85 & 26.11 \\
\hline With & 174.21 & 66.72 & 30.62 \\
\hline$F \times E$ & ns & ns & ns \\
\hline $\mathrm{CV}^{2}(\%)$ & 23.20 & 25.00 & 29.27 \\
\hline
\end{tabular}

ns: not significant. 1 - SO: soybean oil; PF: poultry fat; SOPF: $50 \%$ soybean oil and $50 \%$ poultry offal fat. 2 - CV: coefficient of variation.

The results of the present study show that there was an increase in the serum levels of pancreatic lipase between 24 and 42 days of age, particularly when the emulsifier was added, which is consistent with the reports of Nir et al. (1993), Noy \& Sklan (1995) and Lima et al. (2003), who verified that pancreatic lipase levels increased with bird age. Jeason \& Kellog (1992) mentioned that the lower concentration of that enzyme found in chicks is lower because their enterohepatic circulation is immature, independently from substrate. On the other hand, Krogdhal (1985) argues that pancreatic lipase activity increases with lipid intake.

Gomez \& Polin (1976)

Table 4 - Carcass traits of 42-day-old broilers as a function of fat source and emulsifier inclusion.

\begin{tabular}{|c|c|c|c|c|c|c|c|c|c|}
\hline \multirow{2}{*}{ Parameter } & \multicolumn{2}{|c|}{ Emulsifier (E) } & \multicolumn{3}{|c|}{ Fat source (F) } & \multicolumn{3}{|c|}{ Probability } & \multirow{2}{*}{$\begin{array}{l}\mathrm{CV}^{2} \\
(\%)\end{array}$} \\
\hline & Without & With & SO $^{1}$ & PF1 & SOPF1 & $E$ & $F$ & ExF & \\
\hline $\operatorname{Carc}^{3}, \%$ & 72.43 & 72.15 & 72.75 & 72.27 & 72.85 & ns & ns & ns & 2.21 \\
\hline Head+neck ${ }^{3}, \%$ & 5.66 & 5.51 & 5.50 & 5.67 & 5.59 & ns & ns & ns & 6.89 \\
\hline Feet $^{3}, \%$ & 3.98 & 3.86 & 3.92 & 3.89 & 3.82 & ns & ns & ns & 6.85 \\
\hline Ab. fat ${ }^{3}, \%$ & 1.83 & 1.66 & 1.66 & 1.78 & 1.79 & ns & ns & ns & 24.64 \\
\hline Back $^{3}, \%$ & 20.68 & 21.11 & 21.15 & 20.57 & 20.97 & ns & ns & ns & 7.93 \\
\hline Leg $^{3}, \%$ & 32.64 & 31.82 & 32.05 & 32.65 & 31.97 & ns & ns & ns & 5.62 \\
\hline Breast $^{3}, \%$ & 35.12 & 35.10 & 34.95 & 35.03 & 35.35 & ns & ns & ns & 4.74 \\
\hline Wings $^{3}, \%$ & 11.14 & 11.37 & 11.38 & 11.19 & 11.20 & ns & ns & ns & 6.86 \\
\hline Br. meat ${ }^{3}, \%$ & 26.11 & 25.99 & 26.03 & 25.83 & 26.29 & ns & ns & ns & 5.59 \\
\hline Br. bone $3, \%$ & 5.58 & 5.52 & 5.55 & 5.66 & 5.44 & ns & ns & ns & 8.97 \\
\hline Br. skin³, \% & 3.26 & 3.31 & 3.24 & 3.26 & 3.36 & ns & ns & ns & 18.03 \\
\hline
\end{tabular}

1 - SO: soybean oil; PF: poultry fat; SOPF: $50 \%$ soybean oil and $50 \%$ poultry fat. 2 - CV: coefficient of variation; ns: not significant. 3 - Carc.: carcass yield; head+neck: head and neck yield; feet: feed yield; Ab fat: abdominal fat percentage; Back: back yield; Leg: thigh+drumstick yield; Breast: breast yield; Wings: wings yield; Br. meat: breast meat yield; Br. bone: breast bone percentage; Br. skin: breast skin percentage. observed better fat absorption when bile salts were added to diets. Freeman (1984) mentioned that bile salts emulsify fats, creating smaller particles, thereby favoring the action of lipase, and therefore it may be inferred that, in the present study, the emulsifier increased the availability of lower fat particles, consequently increasing the demand of lipase production (Table 6) and improving ether extract digestibility. 
Table 6 - Pancreatic lipase levels (UI/g pancreas) of 24-day-old broilers (Exp. 2) and 42-day-old broilers (Exp. 1), as a function of fat source and emulsifier inclusion.

\begin{tabular}{|c|c|c|c|c|c|c|c|c|c|}
\hline \multirow{2}{*}{ Age (days) } & \multirow{2}{*}{ Emulsifier (E) } & \multicolumn{3}{|c|}{ Source (F) } & \multirow[t]{2}{*}{ Mean } & \multicolumn{3}{|c|}{ Probability } & \multirow{2}{*}{$\begin{array}{l}C^{2} \\
(\%)\end{array}$} \\
\hline & & $\mathrm{SO}^{1}$ & PF1 & SOPF 1 & & $\bar{E}$ & $F$ & $E \times F$ & \\
\hline \multirow{3}{*}{24} & Without & 19.49 & $20.01 \mathrm{~A}$ & $13.12 \mathrm{~B}$ & 17.54 & & & & \\
\hline & With & 15.48 & 14.85B & $32.09 \mathrm{~A}$ & 20.80 & $<0.05$ & $<0.05$ & $<0.05$ & 24.06 \\
\hline & Mean & 17.48 & 17.43 & 22.60 & & & & & \\
\hline \multirow{3}{*}{42} & Without & 25.91 & $33.58 \mathrm{~B}$ & 19.81B & 26.43 & & & & \\
\hline & With & 33.82 & $51.20 \mathrm{~A}$ & $48.75 \mathrm{~A}$ & 44.59 & $<0.05$ & $<0.05$ & $<0.05$ & 4.51 \\
\hline & Mean & $29, .86$ & 42.39 & 34.28 & & & & & \\
\hline
\end{tabular}

1 - SO: soybean oil; PF: poultry fat; SOPF: $50 \%$ soybean oil and $50 \%$ poultry fat. 2 - CV:coefficient of variation. $A, B$ - Means followed by different capital letters in the same row are significantly different by the $F$ test $(p<0.05)$.

Polin \& Hussein (1982) observed an increase in lipid retention in 7-dayold broilers when bile salts (sodium taurocholate at $0.4 \%$ ) in the diets, whereas the absence of bile salt supplementation reduced fat utilization in $25 \%$ as seven days of age as compared to 14 and 21 days of age. Kussaibati et al.

There was no effect of fat source or of emulsifier on the digestibility of dietary dry matter or crude fiber; however, there was effect of the interaction $(p<0.05)$ between fat source and emulsifier addition on crude protein and ether extract digestibility (Table 7).

Table 7 - Coefficients de apparent digestibility of dry matter (DM), crude protein (CP), crude fiber (CF) and ether extract (EE) of 21- to 23-day-old broilers de 21 a 23 days of age, as a function of fat source and emulsifier inclusion.

\begin{tabular}{|c|c|c|c|c|}
\hline $\begin{array}{l}\text { Source } \\
\text { Fat source (F) }\end{array}$ & $\begin{array}{c}\text { DM, \% } \\
\text { ns }\end{array}$ & $\begin{array}{c}C P, \% \\
p<0.05\end{array}$ & $\begin{array}{c}\text { CF, \% } \\
\text { ns } \\
\end{array}$ & $\begin{array}{c}\text { EE, \% } \\
P<0.05 \\
\end{array}$ \\
\hline $\mathrm{SO}^{1}$ & 75.01 & 64.10 & 43.26 & 93.31 \\
\hline $\mathrm{PF}^{1}$ & 75.04 & 65.68 & 44.32 & 92.72 \\
\hline SOPF1 & 75.81 & 66.52 & 47.70 & 94.98 \\
\hline Emulsifier (E) & ns & $p<0.05$ & ns & $p<0.05$ \\
\hline Without & 75.67 & 69.92 & 47.64 & 92.59 \\
\hline With & 74.90 & 60.95 & 42.54 & 94.74 \\
\hline$F \times E$ & ns & $p<0.05$ & ns & $p<0.05$ \\
\hline $\mathrm{CV}^{2},(\%)$ & 4.52 & 9.58 & 19.54 & 1.77 \\
\hline
\end{tabular}

ns: not significant. 1 - SO: soybean oil; PF: poultry fat; SOPF: $50 \%$ soybean oil and $50 \%$ poultry offal fat. 2 - CV: coefficient of variation.

Broilers fed diets containing soybean oil and poultry offal fat presented better crude protein digestibility $(p<0.05)$ when the emulsifier was not added to the diet (Table 8). As to ether extract digestibility, birds fed the diet with poultry offal fat and supplemented with the emulsifier presented better $(p<0.05)$ digestibility (Table 8).

Table 8 - Details of the effects of the interactions between fat sources and emulsifier on crude protein and ether extract digestibility.

\begin{tabular}{cccccc}
\hline \multirow{2}{*}{$\begin{array}{c}\text { Coefficient de } \\
\text { digestibility, \% }\end{array}$} & \multirow{2}{*}{ Emulsifier } & \multicolumn{3}{c}{ Fat source } & \multirow{2}{*}{ Mean } \\
\cline { 3 - 5 } & & SO $^{\mathbf{1}}$ & PF⿻1 $^{\mathbf{1}}$ & SOPF & \\
\hline \multirow{3}{*}{ Crude protein } & Without & $73.92 \mathrm{~A}$ & $67.04 \mathrm{~A}$ & 68.80 & 69.92 \\
& With & $54.29 \mathrm{~B}$ & $64.31 \mathrm{~B}$ & 64.25 & 60.95 \\
& Mean & 64.10 & 65.68 & 66.52 & \\
& Without & 92.53 & $90.43 \mathrm{~B}$ & 94.82 & 92.59 \\
\multirow{3}{*}{ Ether extract } & With & 94.08 & $95.00 \mathrm{~A}$ & 95.14 & 94.74 \\
& Mean & 93.31 & 92.71 & 94.98 & \\
\hline
\end{tabular}

1 - SO: soybean oil; PF: poultry fat; SOPF: $50 \%$ soybean oil and $50 \%$ poultry fat; $A, B$ Means followed by different capital letters in the same row are significantly different by the $F$ test $(p<0.05)$.
(1982) showed that the supplementation of bile salts in broiler diets increased the digestibility of less saturated fats, such as the blends of animal and vegetable fats. This result is consistent with the better fat digestibility of the diet containing poultry offal fat and emulsifier obtained in the present study.

\section{CONCLUSIONS}

The use of soybean oil, poultry fat and their blend in the diet does not influence the performance, carcass traits, or serum cholesterol, HDL and triglyceride levels of 42-day-old broilers. The addition of emulsifiers to diets containing poultry offal fat improves ether extract digestibility and increases the production and secretion of pancreatic lipase.

\section{REFERENCES}

Andreotti MO, Junqueira OM, Barbosa MJB, Cancherini LC, Araújo LF, Rodrigues EA. Tempo de trânsito intestinal, desempenho, características de carcaça e composição corporal de frangos de corte alimentados com rações isoenergéticas formuladas com diferentes níveis de óleo de soja. Revista Brasileira de Zootecnia 2004; 33(4):870-879.

Araujo JMA. Química de alimentos: teoria e prática. 2. ed. Viçosa: UFV; 1999.

AOAC - Association of Official Analytical Chemists. Official methods of analysis. 15th ed. Arlington: AOAC; 1990. 128 p.

Carew Jr. LB, Machemer Jr. RH, Sharp RW, Foss DC. Fat absorption by very young chick. Poultry Science 1972; 51(3):738-742.

Crespo N, Eesteve-Garcia E. Polyunsaturated fatty acids reduce insulin and very low density lipoprotein levels in broiler chickens. Poultry Science 2003; 82:1134-1139.

Fascina VB, Carrijo AS, Souza KMR, Garcia AML, Kiefer C, Sartori $J R$. Soybean oil and beef tallow in starter broiler diets. Brazilian Journal of Poultry Science 2009; 11(4):249-256.

Ferreira AF, Andreotti MO, Carrijo AS, Souza KMR, Fascina VB, 
Guerreiro Neto AC, Pezzato AC, Sartori JR, Mori C, Cruz VC, Fascina VB

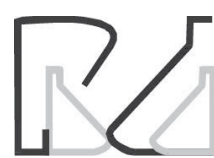

Emulsifier in Broiler Diets Containing Different Fat Sources
Rodrigues EA. Valor nutricional do óleo de soja, do sebo bovino e de suas combinações em rações para frangos de corte. Acta Scientiarum. Animal Science 2005; 27(2):213-219.

Freeman CP. The digeston, absorption and tranport of fats nonruminants. In: Winseman J, editor. Fats in animal nutrition. London: Butterworths; 1984. p.105-122.

Gaiotto JB, Menten JF, Racanicci AMC, Lafigliola MC. Óleo de soja, óleo ácido de soja e sebo bovino como fontes de gorduras em rações de frangos de corte. Revista Brasileira de Ciências Avícola 2000; 2(3):219-227.

Gaiotto JB. Determinação da energia metabolizável de gorduras e sua aplicação na formulação de dietas para frangos de corte [dissertação]. Piracicaba (SP): Escola Superior de Agricultura Luiz de Queiroz; 2004.

Gomez MX, Polin D. Use of bile salts to improve absorption of tallow in chicks, one to three weeks of age. Poultry Science 1976; 55(6):2186-2195.

Jeason SE, Kellog TF. Ontogeny of taurocholate accumulation in terminal ileal mucosal cells of young chicks. Poultry Science 1992; 71:367-372.

Ketels E, De Groote G. Effect of ratio of unsaturated to saturated fatty acids of the dietary lipid fraction on utilization and metabolizable energy of added fats in young chicks. Poultry Science 1989; 68(11):1506-1512.

Krogdhal A. Digestion and absorption of lipids in poultry. Journal of Nutrition 1985; 115(5):675-685.

Kussaibati R, Guillaume J, Leclerq B. The effects of age, dietary at and bile salts, and feeding ration apparent and true metabolized energy values in chickens. British Poultry Science 1982; 23:393403.

Lara LJC, Baião NC, Aguilar CAL, Cançado SV, Fiuza MA, Ribeiro BRC. Rendimento, composição e teor de ácidos graxos da carcaça de frangos de corte alimentos com diferentes fontes lipídicas. Arquivo Brasileiro de Medicina Veterinária e Zootecnia 2006; 58(1):108-115.

Lima ACF, Pizauro Jr. JM, Macari M, Malheiros EB. Efeito do uso de probiótico sobre o desempenho e atividade de enzimas digestivas de frangos de corte. Revista Brasileira de Zootecnia 2003; 32(1):200-207.

Lumeij JT. Avian clinical biochemistry. In: Kaneko JJ, Harvey JW, Bruss ML, editors. Clinical biochemistry of domestic animals. 5th ed. New York. Academic Press; 1997. p. 857-883.

Manilla HA, Husveth F, Nemeth K. Effects of dietary fat origin on the performance of broiler chickens and on the fatty acid composition of selected tissues. Acta Agraria Kaposváriensis 1999; 3(3):47-57.

Matterson LD, Potter LM, Stutz MW, Singsen EP. The metabolizable energy of feed ingredients for chickens. Research Report 1965; 7:3-11.

Nir I, Nitsan Z, Mahagua M. Comparative growth and development of the digestive organs and some enzymes in broiler and egg type chicks after hatching. British Poultry Science 1993; 34:523-532.

Noy Y, Sklan D. Digestion and absorption in young chicks. Poultry Science 1995; 74:366-373.

Ozdogan M, Aksit M. Effects of the feeds containing different fats on carcass and blood parameters of broilers. Journal of Applied Poultry Research 2003; 12:251-256.

Polin D, Hussein TL. The effect of bile acid on lipid and nitrogen retention, carcass composition, and dietary metabolizable. Poultry Science 1982; 61:1697-1707.

Rostagno HS, Albino LFT, Donzele JL, Gomes PC, Oliveira RF, Lopes DC, Ferreira AS, Barreto SLT Tabelas brasileiras para aves e suínos: composição de alimentos e exigências nutricionais. $2^{a}$ ed. Viçosa: Departamento de Zootecnia,UFV; 2005. 186p.

Sanz M, Flores A, Lopez-Bote CJ. The metabolic use of energy from dietary fat in broilers is affected by fatty acid saturation. British Poultry Science 2000; 41:61-68.

Sarda L, Desnuelle P. Action de la lipase pancréatique sur les esters en émulsion. Biochemical Biophysical Acta 1958; 30:513-521.

Sartori JR, Gonzales E, Souza EM, Garcia EA, Wechsler FS. Efeito do período de jejum na fase final de criação de frangos de corte machos sobre rendimento e qualidade de carcaça. Revista Brasileira de Zootecnia 1997; 26(6):1200-1207.

SAS. User's guide, version $6.4^{\text {th }}$ ed. North Caroline: SAS Institute; 1996. 1686p.

Sell JL, Krogdhal A, Hanyu N. Influence of age on supplemental fats by young turkeys. Poultry Science 1986; 65:546-554.

Silva RR, Oliveira TT, Nagem TJ, Pinto AS, Albino LFT, Almeida MR, Moraes HK, Pinto JG Efeito hipolipidêmico dos flavanóides naringina e rutina. Archivos Latinoamericanos de Nutrición 2001; 51(3):258-264.

Vieira SL, Ribeiro AML, Kessler AM, Fernandes LM, Ebert AR, Eichner G. Utilização da energia de dietas para frangos de corte formuladas com óleo ácido de soja. Revista Brasileira de Ciência Avícola 2002; 4(2):1-13.

Zollistsch W, Kraus W, Aichinger F, Lettrer F. Effects of different dietary fat sources on performance and carcass characteristics of broiler. Animal Feed Science Technology 1997; 66:63-73. 